\title{
Uma apresentação de Vera San Payo de Lemos: Sobre escritas, reescritas, e outras coisas que merecem ser ditas
}

\section{Paulo Eduardo Carvalho}

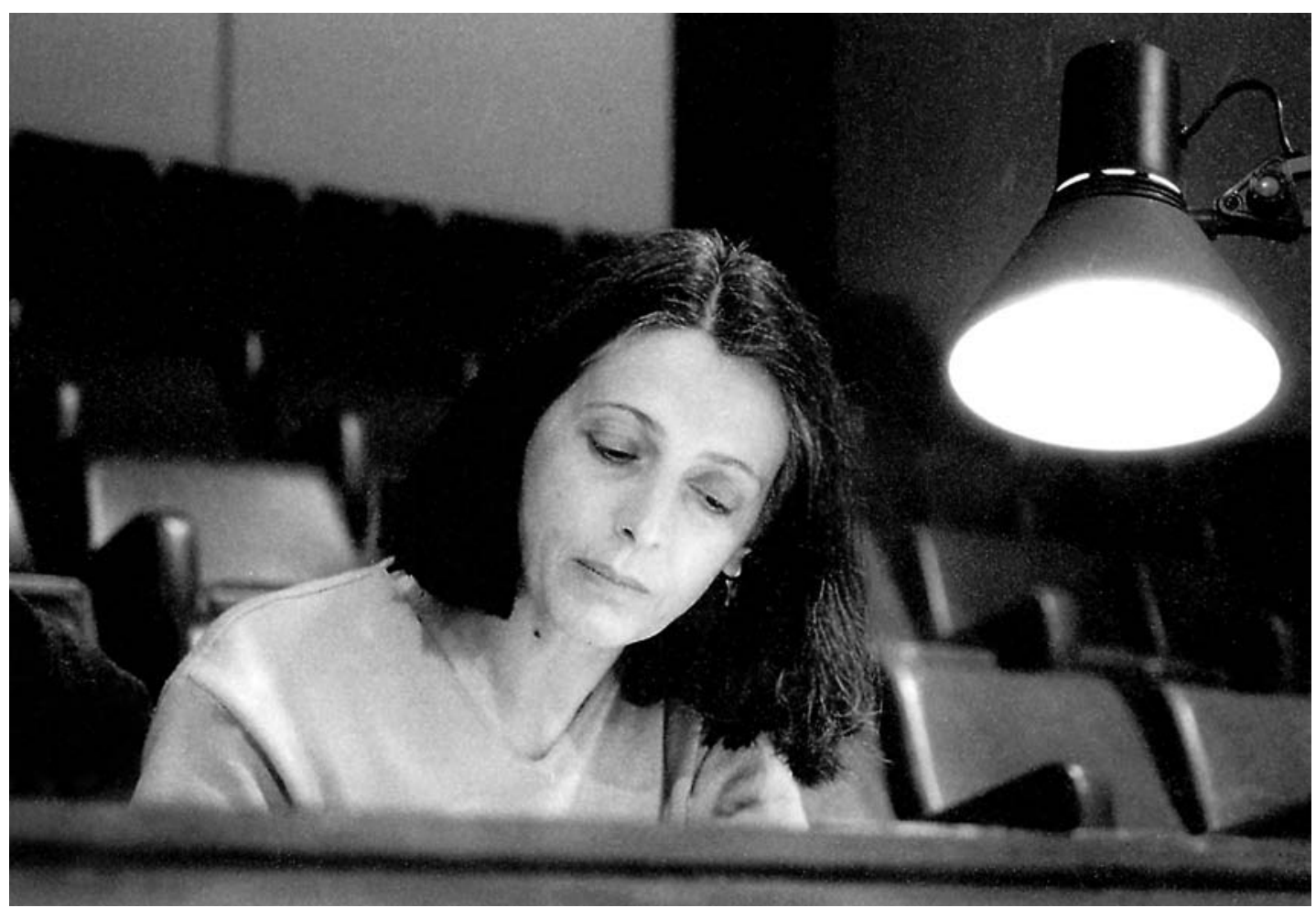

1.

Vera San Payo de Lemos assegurou, em 2003, a tradução, dramaturgia e versão (nesta última valência, em colaboração com o encenador João Lourenço) dos textos para os espectáculos Copenhaga, do inglês Michael Frayn, Demónios menores, do norte-americano Bruce Graham, e O bobo e a sua mulher esta noite na Pancomédia, do alemão Botho Strauss, assim confirmando uma das mais consistentes contribuições criativas para o teatro português contemporâneo. Num ano em que Vera San Payo de Lemos, discretamente, comemora vinte e cinco anos de actividade teatral regular, decidiu um júri composto por cinco membros da Associação Portuguesa de Críticos de Teatro atribuir-Ihe o Prémio da Crítica 2003, deste modo reconhecendo a consistência e a relevância artística do seu contributo para a afirmação, em Portugal, do labor tradutório e dramatúrgico e, por essa via, para a divulgação de textos e autores representativos da dramaturgia contemporânea, com consequências significativas no enriquecimento dos repertórios que, entre nós, vêm sendo construídos.

Desde 1980 - isto é, o ano em que participou nessa experiência fundadora que terá sido a criação portuguesa de Baal, de Bertolt Brecht -, que a tradutora e dramaturgista se tem notabilizado, entre outras coisas, pela revelação entre nós da literatura dramática em língua alemã: recordem-se os muitos textos de Brecht (Baal, A boa pessoa de Setzuan, Ascensão e queda da cidade de Mahagonny, Mãe Coragem e os seus filhos, Happy End, A ópera de três vinténs, bem como os textos para o espectáculo musical 0 mar é azul, azul); mas também as obras de outros dramaturgos alemães, como Friedrich Karl Waechter (Tu e eu), Tankred Dorst (Fernando Krapp escreveu-me esta carta e Merlim), Urs Widmer (Top Dogs), Lutz Hübner (O coração de um pugilista), Oliver Bukowski (Até mais ver), Marius von Mayenburg (Cara de fogo) e Botho Strauss (O tempo e o quarto, Grande e Pequeno e $O$ bobo e a sua mulher esta noite na Pancomédia); e ainda dos austríacos Werner Schwab (As presidentes e Peso a mais, sem peso, sem forma) e Peter Turrini (José e Maria).

Mas a sua actuação tem também, em idêntica medida, privilegiado autores de língua inglesa, sejam eles norteamericanos, tais como Eugene O'Neill (Desejo sob os ulmeiros), 

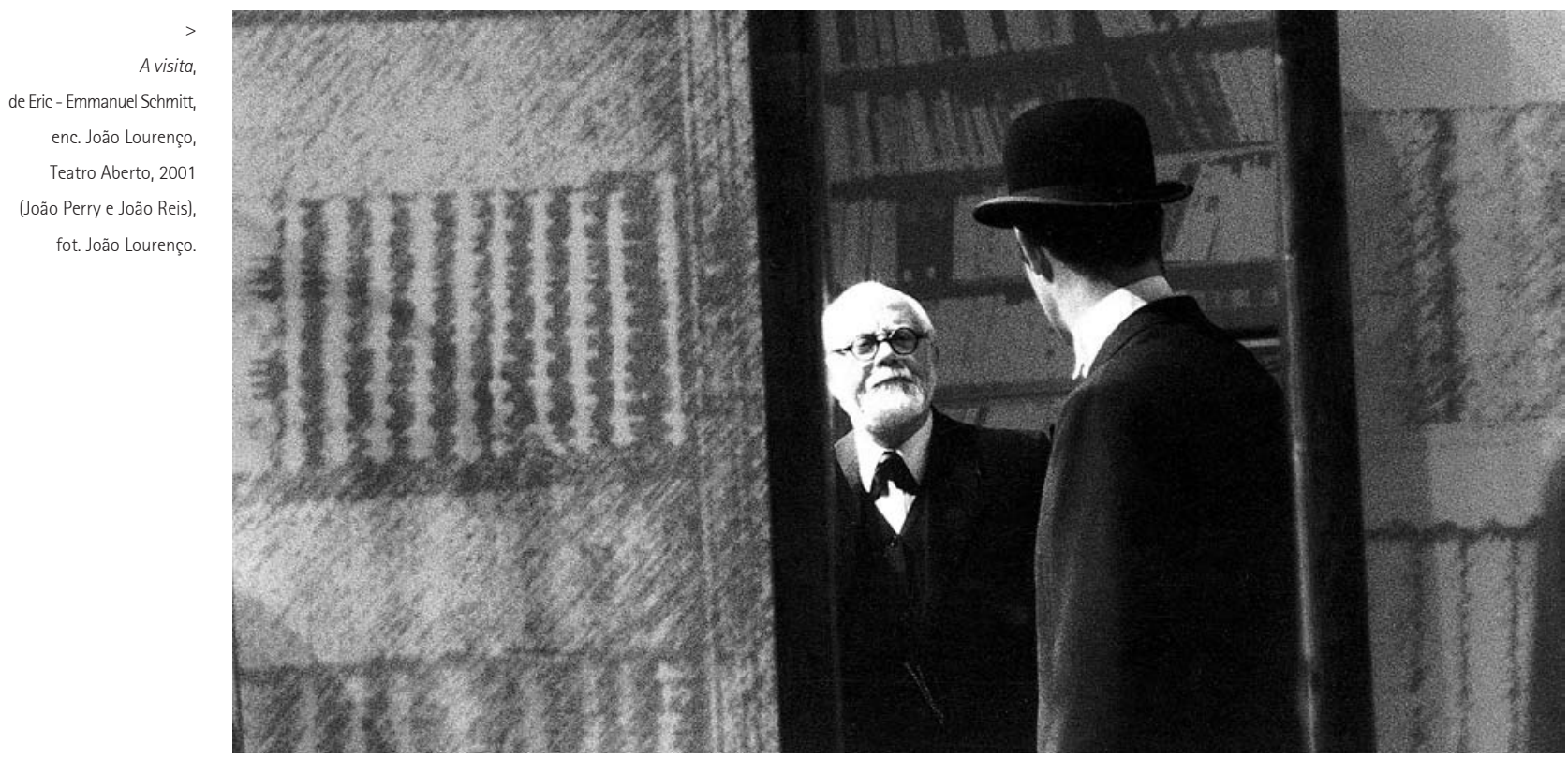

Sam Shepard (Loucos por amore Coração na boca), David Mamet (Oleanna), Neil LaBute (Socos. Peças dos últimos dias e A forma das coisas) e Bruce Graham (Demónios menores), bem como Stephen Sondheim e Hugh Wheeler, autores da obra musical Sweeney Todd; ingleses, como Shakespeare (Romeu e Julieta), Shelagh Delaney (Um sabor a mel), Jim Cartwright (A rua), David Hare (Luz de Inverno), Patrick Marber (Quase), Michael Frayn (Copenhaga); irlandeses, como Frank McGuinness (Alguém olhará por mim) e Conor McPherson (Água salgada e Lucefécit); sulafricanos, como Athol Fugard (O caminho para Meca); e ainda Ariel Dorfman, um argentino que escreve em inglês (A morte e a donzela).

A um total que ultrapassa as quarenta traduções e/ou dramaturgias, será ainda necessário acrescentar os franceses Georges Feydeau (A dama do Maxim's), Jean Anouilh (O ensaio), Bernard-Marie Koltès (Na solidão dos campos de algodão) e Eric-Emmanuel Schmitt (A visita), os russos Tchekov (Jardim das cerejas) e Nikolai Erdman (O suicidário), os italianos Dario Fo e Franca Rame (Oiçam como eu respiro) e o norueguês lbsen (Peer Gynt).

Trata-se de uma "obra" vastíssima cujo verdadeiro alcance se revela extraordinariamente difícil de recuperar e avaliar, desde logo porque a sua existência está intimamente associada à efemeridade da própria experiência teatral, mas também em consequência da "invisibilidade" a que são, inclusive criticamente, tantas vezes, condenadas as operações tradutórias e dramatúrgicas. Relativamente à tradução sobrevive ainda, assaz disseminada, a ideia de que ela será tão mais competente quanto mais "fiel", "fluída" e "transparente" se mostrar (cf. Carvalho, 1999). Aquilo que muitas vezes é menosprezado na, reconhecidamente difícil, tarefa de avaliação crítica deste tipo de intervenção, é a maior ou menor coerência das estratégias e soluções tradutórias relativamente à natureza das propostas cénicas dos espectáculos em que cada um dos textos traduzidos se integra. Uma perspectiva que se revela de particular utilidade quando aplicada ao trabalho de Vera San Payo de Lemos.

No que diz respeito à actividade dramatúrgica, por muito indispensável que ela se revele em qualquer processo de criação cénica, o facto é que, ao contrário do trabalho de um cenógrafo ou de um actor, nem sempre se mostra tarefa fácil identificar algo que possa ser apresentado como prova tangível da contribuição do, ou da, dramaturgista para determinado espectáculo. Se nuns casos, alguns criadores continuam, legitimamente, a recusar a existência ou sequer a necessidade da figura do dramaturgista na equipa criativa, reclamando tais competências para a esfera da sua intervenção autoral, noutros, em que o trabalho de dramaturgia surge efectivamente confiado a um determinado participante ou "cúmplice" criativo, parece esperar-se dele (ou dela), sobretudo, que contribua para a experiência teatral global e para o esforço de todos os criadores envolvidos, não devendo, por isso, assumir nenhum particular protagonismo.

Bernard Dort, responsável pela abertura de uma disciplina de Dramaturgia no Conservatório de Paris no início da década de oitenta, referia-se a esta actividade como "um estado de espírito dramatúrgico. Uma prática transversal. Não uma actividade em si" (Dort 1986: 10), apresentandoa simultaneamente como um "ofício de transição" e uma "prática pedagógica":

Diria, por isso, que o oficio de dramaturgista é um oficio de transição. Também ele deve ser "liquidado" no fogo de artificio da representação. Trata-se, literalmente, de um lugar de passagem. Duvido que se possa ser dramaturgista durante toda a vida. A dramaturgia não se pode contentar consigo mesma. Deve dar lugar ora à escrita, ora à realização de espectáculos. Talvez ela não seja mais do que uma prática pedagógica. Ensina um estado de espírito. Convida os criadores de teatro a tomar consciência da sua actividade. Responsabiliza-os. Torna-os responsáveis pelo sentido ou sentidos das suas realizações. (Dort 1986: 10, tradução minha)

Para lá das formulações inspiradas de Bernard Dort, importará, sobretudo, reconhecer que o papel e as funções do dramaturgista, como figura autónoma e especializada ou não, variam muito conforme os contextos e que, do mesmo modo que não existe um receituário único para a criação teatral, também não existe nenhum modelo para a intervenção dramatúrgica (Cf. Versény 2003: 387; Cardullo 1995). Identificando o lugar da dramaturgia como uma espécie de "enclave ambíguo entre a encenação e o texto", Ana Pais avançou, num estudo recente sobre a dramaturgia, com uma imagem sugestiva, mas de ousada conotação ameaçadora: 
"Dado a sua pluralidade, poderiamos mesmo considerá-la um conceito-hidra, um ser com muitas cabeças que se multiplica em ramificações permanentes" (Pais 2004: 15). A própria Vera San Payo de Lemos teve já, por diversas vezes, a oportunidade de reconhecer que a dramaturgia se apresenta como "uma actividade de múltiplos contornos indefinidos e marcas indistintas" (Lemos 1994: 64).

Tanto a tradução de teatro como o trabalho dramatúrgico constituem áreas de intervenção no processo de criação teatral que, entre nós, por razões várias, só em anos mais recentes vêm merecendo a necessária atenção, tanto a nivel criativo como a nível de comentário e análise. Com a consciência das vantagens e dos riscos de qualquer especialização, impõe-se como um facto mais ou menos indiscutivel que as transformações que o teatro português conheceu nas últimas três décadas se reflectiram de forma expressiva, e nem por isso menos variada, na prática

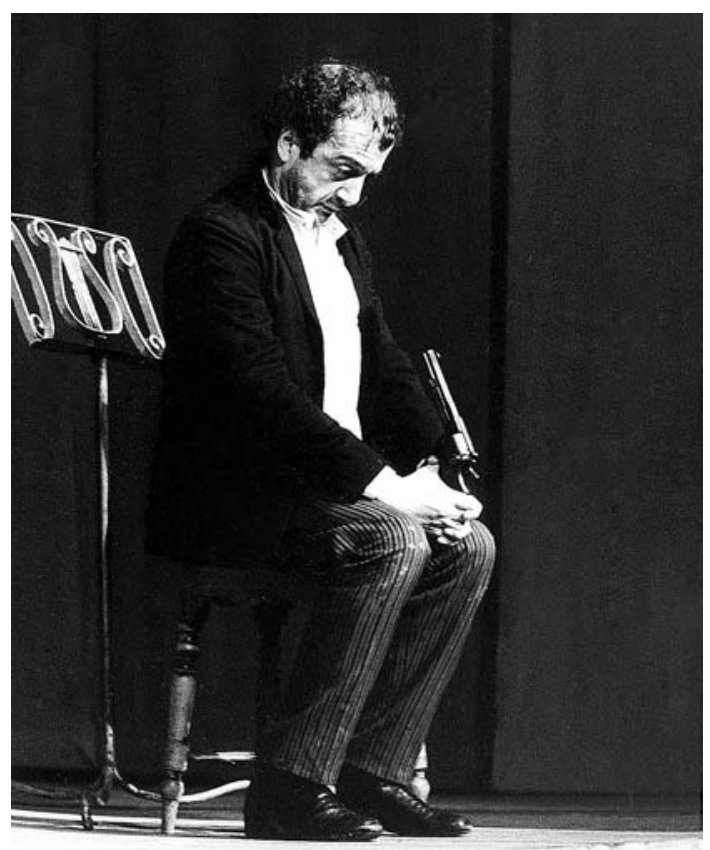

tradutória e dramatúrgica: elevaram-se niveis de exigência, buscaram-se competências, desenvolveram-se métodos, sofisticaram-se as articulações criativas, desenharam-se cumplicidades, definiram-se percursos, num movimento que, genericamente, se pode considerar como decisivamente enriquecedor do tecido teatral português. E é no seio desse vasto território que deveremos tentar cartografar a prática criativa de Vera San Payo de Lemos.

Para uma discussão efectiva e mais justa da dimensão real da actividade desta tradutora e dramaturgista seria, assim, desde logo, necessário entregarmo-nos ao prazer da activação da memória, nossa e alheia, dos espectáculos em que participou. Mas, sem dúvida, que para um comentário de maior profundidade e alcance, seria igualmente imperativo estudar todos os textos dramáticos traduzidos e "reescritos" por Vera San Payo de Lemos, muitos deles em produtiva colaboração com outros criadores - e como seria útil, aqui, se beneficiássemos da tradição alemã de publicar "livrosprograma" em que se reproduzem integralmente os textos das peças, indicando os cortes e as transformações introduzidas -, bem como todos os outros textos originalmente escritos a propósito de cada uma dessas aventuras. Seria ainda necessário recuperar reacções críticas, ponderar impactos públicos, aprofundar os métodos de trabalho praticados pelos diversos criadores envolvidos, e entrevistar não só a própria tradutora e dramaturgista, mas também muitos dos seus mais próximos colaboradores, etc.

Ao deixar aqui tão toscamente esboçado um mais do que justo e merecido projecto de trabalho, pretende-se, sobretudo, advertir para o facto de estas palavras se oferecerem simplesmente como a sinalização possivel, e necessariamente provisória, senão mesmo precária, de uma obra que justifica, para lá do reconhecimento que agora lhe é prestado, uma atenção muito mais empenhada e disponivel para atender à complexidade das operações constitutivas do tipo de labor criativo que lhe está associado (vejam-se, contudo, os estudos parcelares de Carrington 1991, e Teixeira 1998). Proponho-me, assim, baseado numa pequena amostra de alguns dos materiais indicados, esboçar breves apontamentos e reflexões, avançando com algumas hipóteses de caracterização do percurso criativo de Vera San Payo de Lemos.

Acrescente-se, ainda em jeito preambular, que a atribuição deste prémio constitui também uma rara oportunidade para combater a já discutida "invisibilidade" do labor tradutório e dramatúrgico - de que a "discrição", pessoal e profissional, praticada pela premiada é imagem paradigmática (cf. Nunes 2003). Parece-nos, de facto, necessário e urgente que esse labor seja arrancado dos bastidores onde habitualmente se desenvolve e refugia, deslocando-o para o centro da cena, pois esse é o lugar para uma mais justa discussão da imensa variedade de procedimentos envolvidos. É nesse sentido que se procederá à exposição de algumas das suas estratégias e à valorização dos seus mais positivos contributos.

\section{2.}

Com uma formação linguística e literária na área dos estudos alemães e ingleses, a actual dramaturgista residente do Novo Grupo/Teatro Aberto deve à obra de Brecht as suas experiências formadoras no domínio do teatro, primeiro, em meados dos anos 70, com a tradução de alguns textos para um seminário de actores orientado pelo director do Centro Brechtiano de Berlim, realizado na Fundação Calouste Gulbenkian, e depois, em 1980, com a já referida participação nessa aventura que terá constituido a primeira criação portuguesa de Baal. Tratou-se de um espectáculo com encenação de João Lourenço (que já tinha, entre 1975 e 1976, encenado As espingardas da mãe Carrar e 0 círculo de giz caucasiano) e interpretação de Mário Viegas e João
Osuicidário,

de Nikolai Erdman, enc. João Lourenço, Teatro Aberto, 1983 (Mário Viegas), fot. João Lourenço. 


\section{Peer Gynt, de Henrik Ibsen, enc. João Lourenço, Teatro Aberto, 2002 (João Pedro Vaz), fot. Ramon de Melo.}

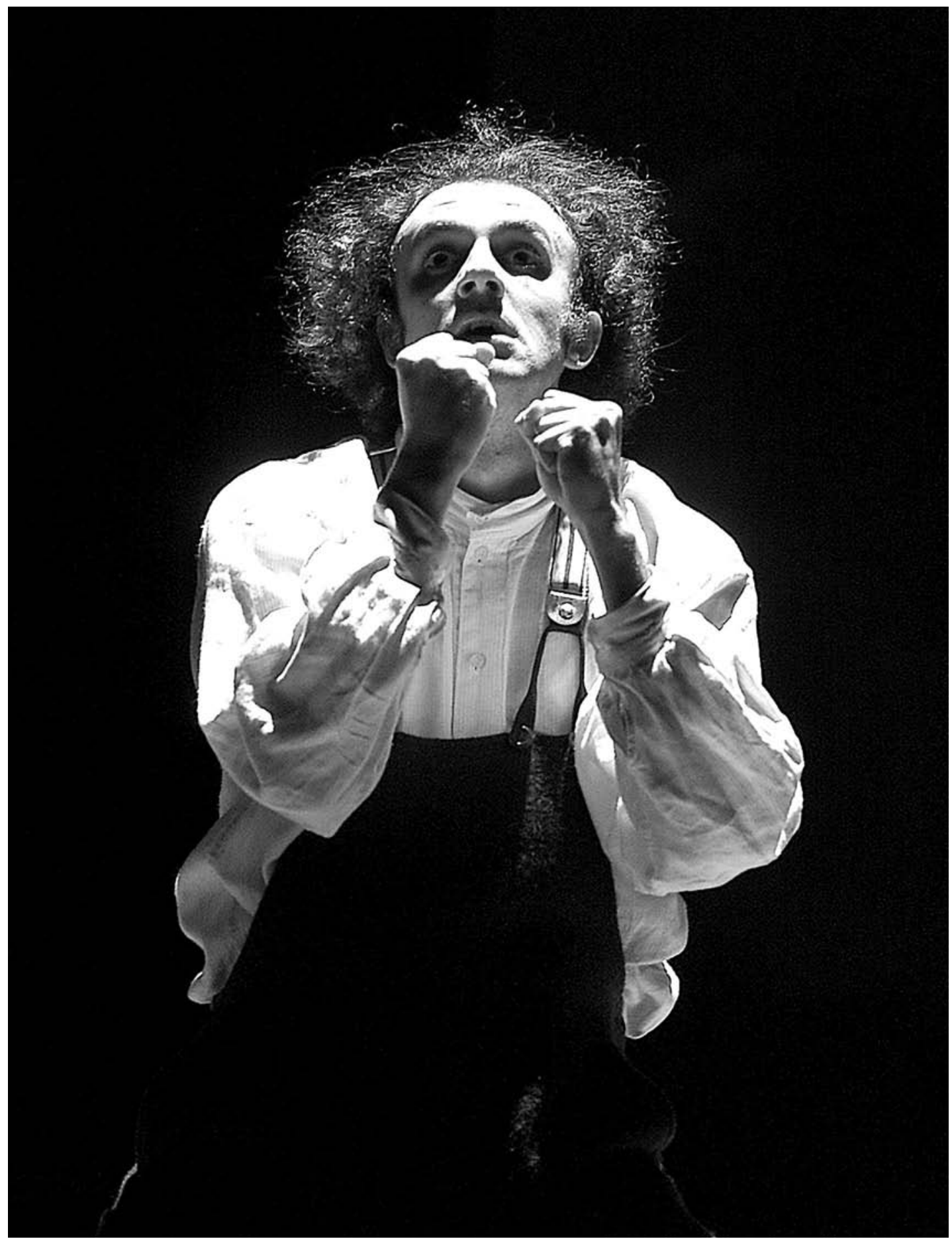

Perry, que a própria tradutora e dramaturgista já descreveu em termos sugestivamente fundadores: "O que tinha começado por parecer uma aplicação prática de estudos literários a uma área especifica, o teatro, acabou por ser um primeiro trabalho de dramaturgia" (Lemos 1994: 66). Para além de uma dissertação de mestrado, em 1988, dedicada à obra do jovem Brecht, Vera San Payo de Lemos participaria, até 1998, em mais seis espectáculos baseados na obra do dramaturgo alemão, sempre em colaboração com o encenador João Lourenço e, muitas vezes, também com a participação de José Fanha: A boa-pessoa de Setzuan (1984), Ascensão e queda da cidade de Mahagonny (1985), Mãe Coragem e os seus filhos (1986), Happy End (1989), A ópera de três vinténs (1992), e o espectáculo de canções O mar é azul, azul (1998).
Este núcleo de experiências práticas e de investigação em torno da obra de Brecht afirma-se como determinante no desenvolvimento de alguns dos procedimentos mais característicos da intervenção dramatúrgica de Vera San Payo de Lemos. Numa reflexão, singularmente esclarecedora, como é seu hábito, que em 1994 dedicou à exposição de alguns "pontos e linhas" da sua prática dramatúrgica, Vera San Payo de Lemos invoca os nomes de Lessing, com a sua Dramaturgia de Hamburgo, de 1767 - momento efectivamente fundador de um entendimento da dramaturgia como "consciência crítica" do espectáculo teatral -, e de Brecht, criador ao qual, sobretudo no contexto do Berliner Ensemble, se ficará a dever uma mais clara autonomização do papel do dramaturgista, doravante integrado como elemento de pleno direito na 
equipa responsável pela criação do espectáculo.

0 estabelecimento desta deliberada e consciente genealogia esclarece, primeiro, um entendimento do trabalho dramatúrgico como decisivamente centrado no texto e em tudo aquilo que implica a sua material "passagem à cena", e, segundo, uma mais complexa, e porventura rica, negociação autoral, na medida em que, à imagem da prática dramatúrgica brechtiana, o texto a traduzir, a "verter" e a encenar, se oferece como um material apropriável e reconfigurável, em função das mais diversas coordenadas, determinadas, desde logo, por um novo contexto criativo e de comunicação com o público.

Numa outra reflexão que dedicou à tradução de $A$ ópera de três vinténs, Vera San Payo de Lemos insiste, sempre que se trate de traduzir Brecht "para o teatro", não só na necessidade de "reflectir sobre a teoria e a prática do teatro épico por ele desenvolvido", mas também na legitimidade, senão mesmo na justa pertinência, de replicar "principios e estratégias semelhantes às que enformaram as fases de tradução e recriação" das suas próprias "versões" - tal como aconteceu com o trabalho, realizado por Elisabeth Hauptmann, Brecht e Weill, em 1928, sobre The Beggar's Opera, de John Gay. Reafirmando a convicção de que "traduzir Brecht para o teatro é interpretar os seus textos e recriá-los aqui e agora", A ópera de três vinténs que se oferecia ao público português, em 1992, era uma "versão própria (...) marcada desde o início pelas escolhas do projecto de encenação e depois alterada, cortada e acrescentada ao longo do processo de trabalho, dos ensaios até à estreia". Apoiadas numa lúcida consciência da necessidade de um "tratamento diferenciado dos elementos dramáticos, narrativos e lírico-musicais" do texto original, as operações de reescrita incluíram, neste caso, por exemplo, a ampliação das funções dramatúrgicas da personagem do cantor de rua, a que não terá sido alheia a "personalidade do intérprete" (Fernando Gomes) e a sua facilidade de contacto directo com o público (cf. Lemos 1998: 215).

Apresentados como "versões", os diversos textos de Brecht fixados para os espectáculos já referidos exibem, assim, inúmeros exemplos de "cortes ou alterações de sequências de cenas e falas isoladas" ou "acrescentos e modificações em relação ao texto original". Dois outros exemplos: em Mãe Coragem e os seus filhos, é criada a personagem do "soldadode-todos-os-tempos", uma figura com acrescidas funções narrativas retirada de uma história de almanaque do autor alemão, "0 soldado de La Ciotat", introduzida na versão portuguesa para, de algum modo, potenciar os propósitos "anti-ilusionistas" de Brecht; em Ascensão e queda da cidade de Mahagonny, a figura do apresentador-narrador é transformada num realizador de cinema que está num teatro de ópera para filmar aquele espectáculo, tendo-Ihe sido atribuídos dois tipos de discurso: um texto de narrador, escrito a partir das réplicas originais do apresentador, e um texto de realizador, escrito pelos próprios autores da versão.

A lição brechtiana de desenvoltura nas operações dramatúrgicas combinada com esta propensão para "aproximar a acção das pessoas", centrando-a no "aqui e agora", explica, por exemplo, a decisão de "ir ao passado buscar a história de Romeu e Julieta para a contar num palco de hoje, ao público do final da década de oitenta, num português bom de ler, dizer e ouvir", do mesmo modo que explica a opção por introduzir nessa tragédia romântica de Shakespeare a figura de um "clown" capaz de "quebrar a quarta parede da ilusão, aproximar-se do público e lembrar-Ihe que está a assistir a um espectáculo e que a realidade é outra coisa" (Lemos 1988a).

Paralelamente à abundância de material recolhido em torno dos textos e das experiências cénicas, à utilização de uma vasta bibliografia crítica e à natureza aturada e atenta do trabalho desenvolvido (cf. Teixeira 1998: 80), verifica-se uma nítida, e legítima, tendência, em muitos dos espectáculos, para aproximar as peças do público-receptor, tendo em conta um certo entendimento dos aspectos do tempo e do lugar da representação, com o propósito claro de facilitar a tarefa do espectador na apreensão correcta dos sentidos produzidos pelo espectáculo. Se o gesto resulta assimilador - na medida em que a estranheza do original é substituída por sinais mais reconheciveis na cultura receptiva (cf. Aaltonen 2000: 55) -, não é menos verdade que ele dá novo sentido ao entendimento da "tradução" como um momento mais no crescimento do original.

Vera San Payo de Lemos tem-se empenhado na demonstração, prática e teórica, de uma clara distinção entre "tradução de teatro" (destinada à leitura, esta seria mais académica e filologicamente rigorosa) e "tradução para teatro" (necessariamente mais pragmática), experiências às quais corresponderiam horizontes de expectativas distintos $\mathrm{e}_{1}$ consequentemente, distintas estratégias de tradução. Tal oposição, apresentada com contornos quase ontológicos que mereceriam, penso, uma mais complexa e apurada problematização, descreve não tanto a realidade mais vasta da tradução de teatro tal como é diversamente praticada pelos mais variadores criadores, nos mais diversos contextos criativos, mas antes um entendimento próprio da sua actuação e experiência e, nesse sentido, impõe-se como uma perspectiva de extraordinária utilidade na identificação das diversas estratégias por si praticadas. Se permanece como discutivel a sobrevivência de um paradigma linguistico no olhar que é lançado sobre as relações entre o texto e a cena, esta caracterização oferece-nos uma ideia clara do labor de intensa "recriação" envolvido neste seu entendimento da intervenção tradutória e dramatúrgica:

Direccionada para um projecto concreto de encenação num determinado espaço e tempo, com um elenco de actores, cenógrafo, figurinista, compositor, coreógrafo, luminotécnico e sonoplasta definidos, a tradução feita para o teatro não só revela nas suas escolhas linguisticas as marcas do contexto em que se insere, como também se apresenta flexivel e aberta a ser objecto de sucessivas transformações ao longo do processo de trabalho dos ensaios até à estreia. No conjunto de sinais verbais e não-verbais que compõem o texto final do espectáculo, a tradução que serviu de base e ponto de partida para o processo de criação do espectáculo vai sendo traduzida para as outras linguagens teatrais e, nesse processo, 
Água salgada, de Conor McPherson, enc. João Lourenço, Teatro Aberto, 1997 (Paulo 0om, Tobias Monteiro e José Jorge Duarte), fot. João Lourenço.

Lucefécit, de Conor McPherson, enc. João Lourenço, Teatro Aberto, 2000 (Luis Alberto, José Boavida, António Cordeiro, Francisco Pestana e Catarina Furtado), fot. João Lourenço.

Alquém olhará por mim, de Frank McGuinness, enc. João Lourenço, Teatro Aberto, 1994 (Orlando Sérgio, Diogo Infante e João Perry). fot. João Lourenço. geralmente encurtada e transformada em tipos de texto bastante diferentes, designados por versão, adaptação ou recriação segundo o grau de proximidade ou afastamento em relação ao texto original e ao contexto cultural em que surgiu. (Lemos 1998: 116)

0 reconhecimento da apropriação do modelo brechtiano deve, por tudo isto, ser temperado pela consciência de que têm sido muito diversas as manobras tradutórias e dramatúrgicas efectivamente realizadas no terreno por Vera San Payo de Lemos, como diversos são os procedimentos, de alguma forma ditados pelas características do próprio texto, pelas modalidades de aproximação a esse mesmo texto em circunstâncias concretas, pelo processo particular de construção do espectáculo e até pela dinâmica que se gera entre todos os que nele participam.

Permito-me um exemplo, entre muitos outros possiveis: enquanto na "reescrita" de Água salgada (1997) e Lucefécit (2000), duas peças do irlandês, Conor McPherson, se optou pela completa transferência da acção para contextos portugueses, com a mais radical e imaginativa "adaptação" da ficção dramática da segunda daquelas peças a uma aldeia alentejana, aos seus hábitos e tradições, na tradução de Alquém olhará por mim, de um outro irlandês, Frank McGuinness, manteve-se o quadro ficcional proposto pelo autor - o encontro forçado de três prisioneiros, um norteamericano, um inglês e um irlandês, numa cela no Líbano -, eliminando simplesmente algumas referências topográficas e históricas, e expandindo ou esclarecendo outras (para mais desenvolvimentos, cf. Carvalho 2002).

A atracção por Brecht pode também explicar uma certa preferência por formas dramáticas parabólicas ou próximas da parábola, não só como modo de obviar a uma certa falência do realismo, mas também como modo de prosseguir, com base numa "atitude heurística ligeira", como sugere Jean-Pierre Sarrazac (Sarrazac 2002: 11), a aposta nas faculdades de reflexão e de questionamento pessoal do espectador. No seu texto "Sobre A boa pessoa de Setzuan, de Bertolt Brecht", Vera San Payo de Lemos convoca as palavras do dramaturgo alemão elogiando a particular argúcia e eficácia narrativa da parábola e apresentando-a como um verdadeiro "ovo de Colombo, porque é concreta na abstracção, na medida em que faz ressaltar o que é essencial" (Brecht apud Lemos, 1984). A propósito de Mãe Coragem e os seus filhos, a dramaturgista explica a utilização da parábola por Brecht como uma estratégia para:

fazer ressaltar a variedade, variabilidade e complexidade das formas de comportamento humano, os motivos que a condicionam e as situações em que surgem, não com a finalidade de indicar ao espectador as linhas de comportamento que deverá seguir, mas antes com a finalidade de suscitar o reconhecimento das contradições humanas e a reflexão crítica sobre um mundo em constante mudança (Lemos 1986: 44).

Assim é, por exemplo, que As presidentes (1996), desse "moralista empenhado" que foi Werner Schwab, nos surge
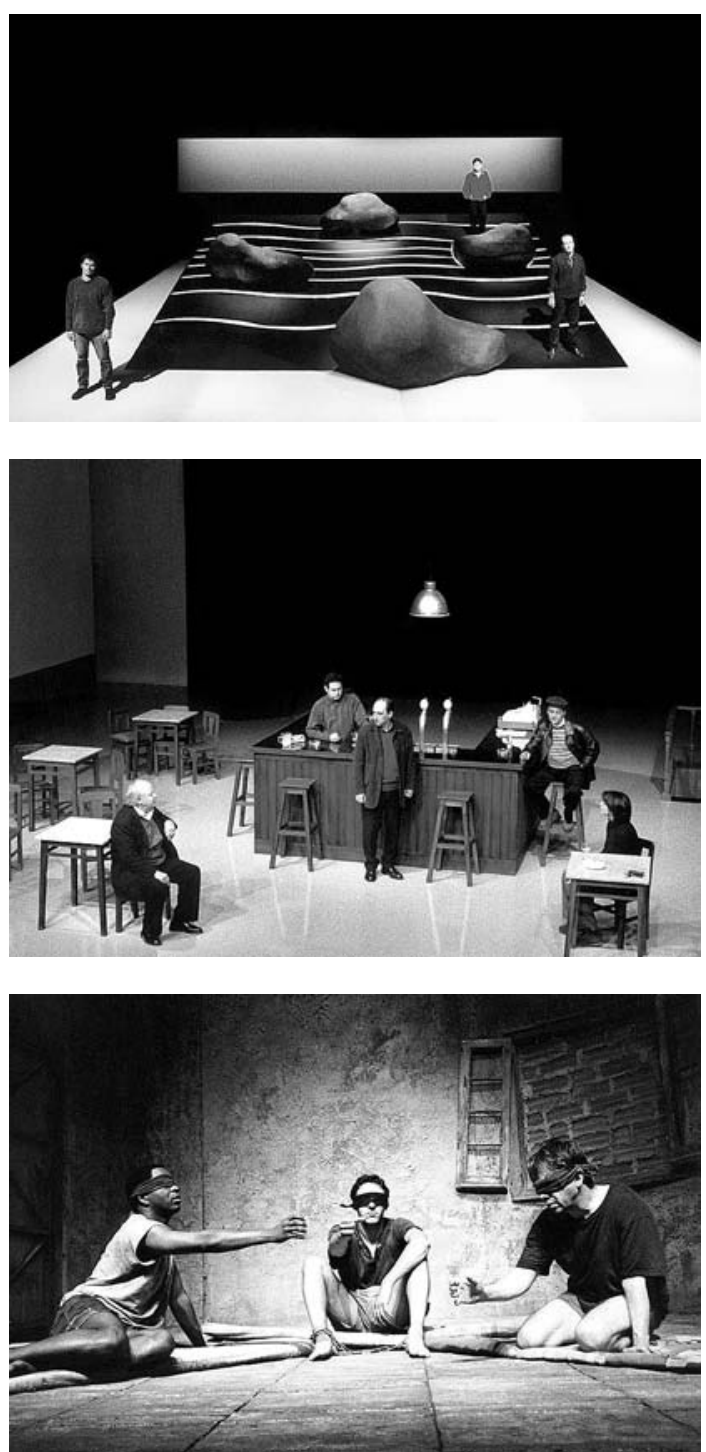

apresentado como uma "parábola sobre o estado em que vai o mundo" (Lemos 1996), de forma distinta, mas não muito distante do "grande teatro do mundo" que nos oferecem as peças de Botho Strauss (o dramaturgo, a seguir a Brecht, do qual Vera San Payo de Lemos traduziu mais peças):

Na escrita de Botho Strauss, as implicações deste olhar sobre a situação do ser humano no mundo revelam-se essencialmente de duas formas: na fuga para a frente, que se exprime na tentativa de acompanhar o compasso acelerado dos momentos fugazes dos tempos modernos e na elaboração do fragmento, do esboço e do instante de significados

múltiplos, e na fuga para trás, que se reflecte na nostalgia por totalidades de sentido e na procura de uma 'estética da restauração' que valoriza a memória, o peso do passado e a força dos mitos. (Lemos 2003b: 18).

0 sonho do teatro como formador e reformador de consciências, como um instrumento privilegiado para combater o "desconcerto do mundo", surge renovado na interpretação da personagem Salomão, de A rua (1988), do inglês Jim Cartwright, uma dessas figuras brechtianas que "entram e saem da acção para contar ou mostrar o que consideram digno de nota (...) apelar para a razão e estimular a reflexão do espectador para, por fim, o tornar bem consciente da necessidade de transformar aquele mundo tão sórdido e desolador num mundo melhor" (Lemos 1988b). 

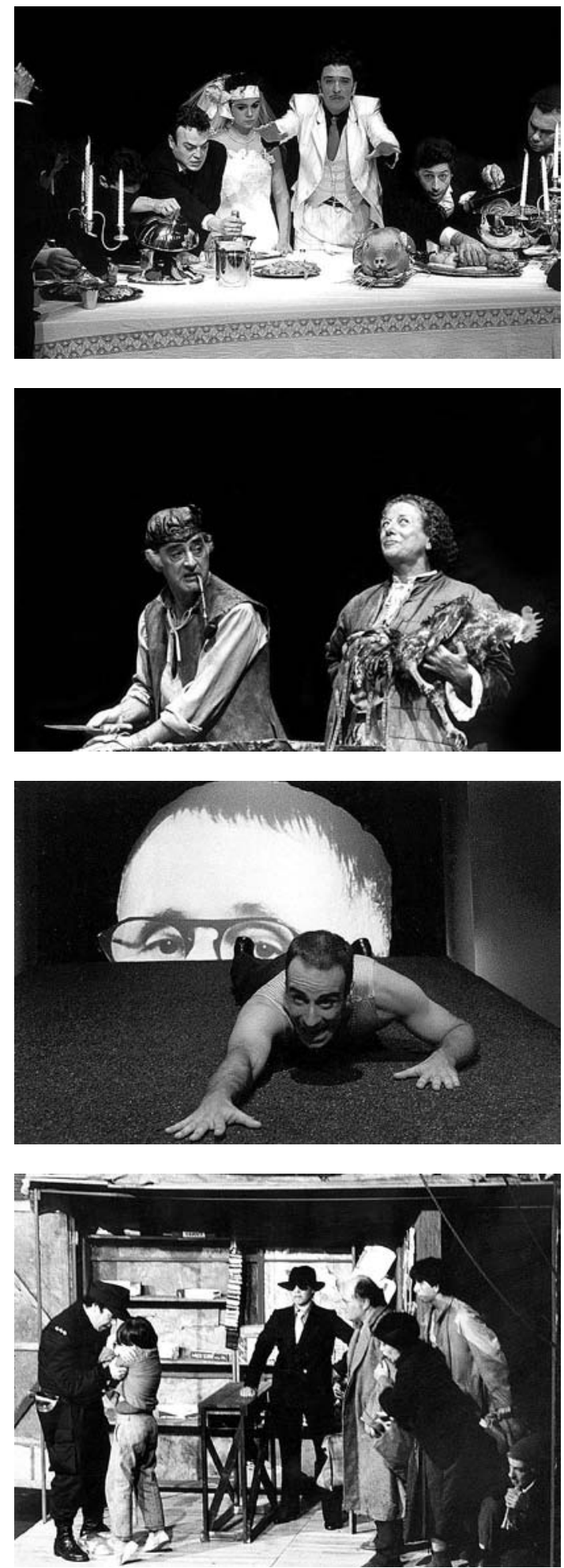

3.

Muito diversos, mas igualmente reveladores, são os muitos textos que Vera San Payo de Lemos foi escrevendo para os programas dos espectáculos em que colaborou. Trata-se de uma vasta produção discursiva que, com a justa sinalização do circunstancialismo histórico da sua emergência, mereceria a sua reunião e publicação conjunta, não só pela extraordinária utilidade das informações que sistematiza, mas também pela riqueza dos olhares propostos sobre determinadas realidades dramáticas e teatrais. Nunca será demais sublinhar a importância desses textos originais que tão largamente contribuem para a reverberação da experiência proporcionada pelo espectáculo. Mas aquilo que resulta como particularmente estimulante no caso de Vera San Payo de Lemos é, como sugeria, a extraordinária diversidade de registos adoptados para a articulação de saberes e perspectivas.

Recordo aqui tanto textos com uma estrutura mais ortodoxa, mas nunca academizante, como outros em que a dramaturgista se deixa tentar por modelos mais arriscados, como aquele em que, a propósito da produção da dupla norte-americana de Desejo sob os ulmeiros e Loucos por amor (1990), põe em diálogo Eugene O'Neill e Sam Shepard (combinando a montagem de excertos de entrevistas, cartas e outros textos daqueles dois dramaturgos, com reflexões próprias), ou aquele outro destinado à apresentação de uma das grandes peças britânicas dos anos 80 , a já referida A rua (1988), em que "o senhor Brecht" é ficcionalmente confrontado com o texto de Jim Cartwright, desse modo ensaiando uma penetrante caracterização de novas modalidades de construção dramática e de interpelação do real:

Também ele, anos atrás, fizera dramas de retalhos, mas, pensando bem, ainda alinhados dentro dos padrões tradicionais da causalidade e da racionalidade. (...) Em vez da clareza da racionalidade a apontar para a imagem de um mundo melhor, o foco concentrava-se agora sobre a subjectividade, fragmentada e problemática, do individuo que chama a atenção sobre si, enchendo o espaço com o seu corpo e a sua voz monologante. É a partir do individuo concreto, das suas mágoas e dos seus desejos particulares, que se olha para o mundo e aparece a imagem, multifacetada, do que o mundo é e deveria ser. (...) Apelando mais aos sentidos e às emoções do que à razão, o espectáculo de Salomão produzia, pelo menos no Senhor B., um efeito semelhante ao que ele em tempos definira por efeito de estranheza: espanto e um ligeiro incómodo, propicios a desencadear a reflexão. (Lemos 1986)

Poderemos ainda referir o caso de textos mais complexos e com uma mais exigente elaboração, como aquele que organiza a propósito de 0 suicidário (1983), desse quase desconhecido, contemporâneo de Meyerhold, que foi Nikolai Erdman, e em torno do qual se tentam recuperar coordenadas histórico-sociais, artísticas e dramatúrgicas capazes de potenciar a recepção do próprio espectáculo. Alguns outros bons exemplos dessa diversidade de registos adoptados incluem a "Conversa para ouvidos de gravador", o registo ficcionalizado e em discurso directo das ideias trocadas pelos três autores de Ubu português - 2002 Odisseia no Terreiro do Paço (1984), no qual se explicitam as razões e as estratégias adoptadas na adaptação da peça de Jarry à realidade portuguesa do momento; mas também o "Diário de trabalho" que recupera a experiência em torno de Ascensão e queda da cidade de Mahagonny; ou ainda o "Epistolário real e fictício sobre a Carta de Fernando Krapp" (1997), a propósito do texto de Tankred Dorst; e o quase poema, com o título sugestivo "O sonho da aflição", que a dramaturgista escreve "no divã de Freud", motivado por A visita (2001), de Eric-Emanuel Schmitt.

\section{A ópera de três vinténs, de Brecht/Weill, enc. João Lourenço, Teatro Aberto, 1992 (ao centro, Sofia Portuga e Fernando Luis), fot. João Lourenço.}

Mãe Coragem e os seus filhos, de Brecht, enc. João Lourenço, Teatro Nacional D. Maria II 1986

(Ruy de Carvalho e Eunice Muñoz) fot. João Lourenço.

O mar é azul, azul, de João Lourenço, José Fanha e Vera San Payo de Lemos, enc. João Lourenço, Teatro Aberto, 199 (José Jorge Duarte), fot. João Lourenço.

A boa pessoa de Setzuan de Brecht, enc. João Lourenço,

Teatro Aberto, 1984 (ao centro, Irene Cruz), fot. João Lourenço. 
de Jim Cartwright, enc. João Lourenço,

Teatro Aberto, 1988 (ao centro, Virgilio Castelo), fot. João Lourenço.

Loucos por amor

de Sam Shepard, enc. João Lourenço, Teatro Aberto, 1990

(Virgilio Castelo e António Filipe), fot. João Lourenço.

Desejo sob os ulmeiros, de Eugene O'Neill enc. João Lourenço, Teatro Aberto, 1990 (Rogério Paulo, Irene Cruz e Fernando Luis),

fot. João Lourenço.

de David Mamet enc. João Lourenço, Teatro Aberto, 1994 (Francisco Pestana e

Sofia Portugal), fot. João Lourenço.
E não esqueçamos, para lá dos textos escritos, os magníficos documentos que constituem muitos dos programas coordenados pela dramaturgista - afinal de contas, aqueles objectos que, nas suas próprias palavras, se oferecem como "o produto mais específico e visivel do trabalho de dramaturgia" (Lemos 1994: 67) - de que são exemplo mais recente aqueles dedicados a Peer Gynt (2002), de Ibsen, e a 0 bobo e a sua mulher esta noite na Pancomédia (2003), de Botho Strauss.

4.

No quadro de uma categorização amplamente reconhecida, podemos afirmar que Vera San Payo de Lemos vem juntando à sua experiência no domínio da "dramaturgia do espectáculo" uma não menos determinante responsabilidade "institucional". Refiro-me à actividade que, no âmbito de uma estrutura de produção e criação teatral como é uma companhia de teatro, diz respeito à selecção de um repertório e à elaboração de uma lógica programática, desse modo contribuindo de forma decisiva para a prossecução dos objectivos da companhia e, consequentemente, para a construção da sua imagem junto do público. Embora partilhe, seguramente, tais funções com a direcção do Novo Grupo, com particular relevo na figura do seu mais regular cúmplice criativo, o encenador João Lourenço, não será arriscado imaginar que à sua atenção e interesses se deverão também algumas das propostas que têm feito a história repertorial daquela companhia. Para lá das peças de temática mais acentuadamente social, levadas à cena no início dos anos 80, dos diversos textos de Brecht que, na mesma década, foram estreados ou revisitados nomeadamente em espaços com um diverso capital simbólico como o Teatro Nacional D. Maria II e o Teatro Nacional de S. Carlos -, e das incursões em territórios mais clássicos, como os de Shakespeare e Tchekov, explorados no final da década de 80 , haverá que realçar a pluralidade de novos textos e novos autores produzidos e encenados pelo Novo Grupo, em consequência da aposta decidida numa programação voltada para a nova dramaturgia universal, nela incluindo a portuguesa.

Tal como resulta claro da lista de autores traduzidos apresentada no início deste texto, não obstante o lugar importante ocupado pela obra de Brecht entre os objectos da atenção dramatúrgica de Vera San Payo de Lemos, são muito mais numerosos e variados os universos dramáticos explorados, devendo-se à sua intervenção ora a absoluta revelação, ora a continuada e empenhada divulgação de dramaturgos nossos contemporâneos. Ao seu esforço, e ao trabalho do Novo Grupo, se fica a dever o nosso conhecimento de grande parte dos autores e dos textos em lingua alemã que, nas duas últimas décadas, têm, em português, visitado os nossos palcos - Friedrich Karl Waechter, Urs Widmer, Oliver Bukowski, Werner Schwab, Peter Turrini, Botho Strauss... -, do mesmo modo que, no domínio do drama em língua inglesa, Ihe ficamos a dever a revelação de figuras diversamente representativas da cena actual como os ingleses Jim Cartwright e Patrick Marber, os irlandeses Frank McGuinness e Conor McPherson, ou ainda o norte-americano Neil LaBute.
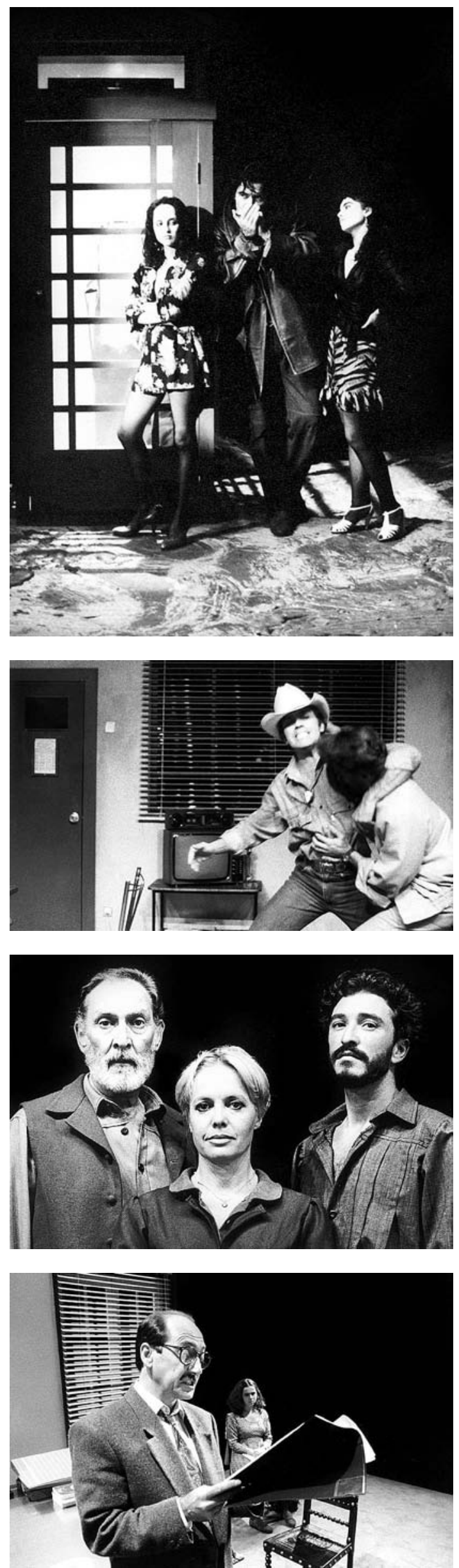

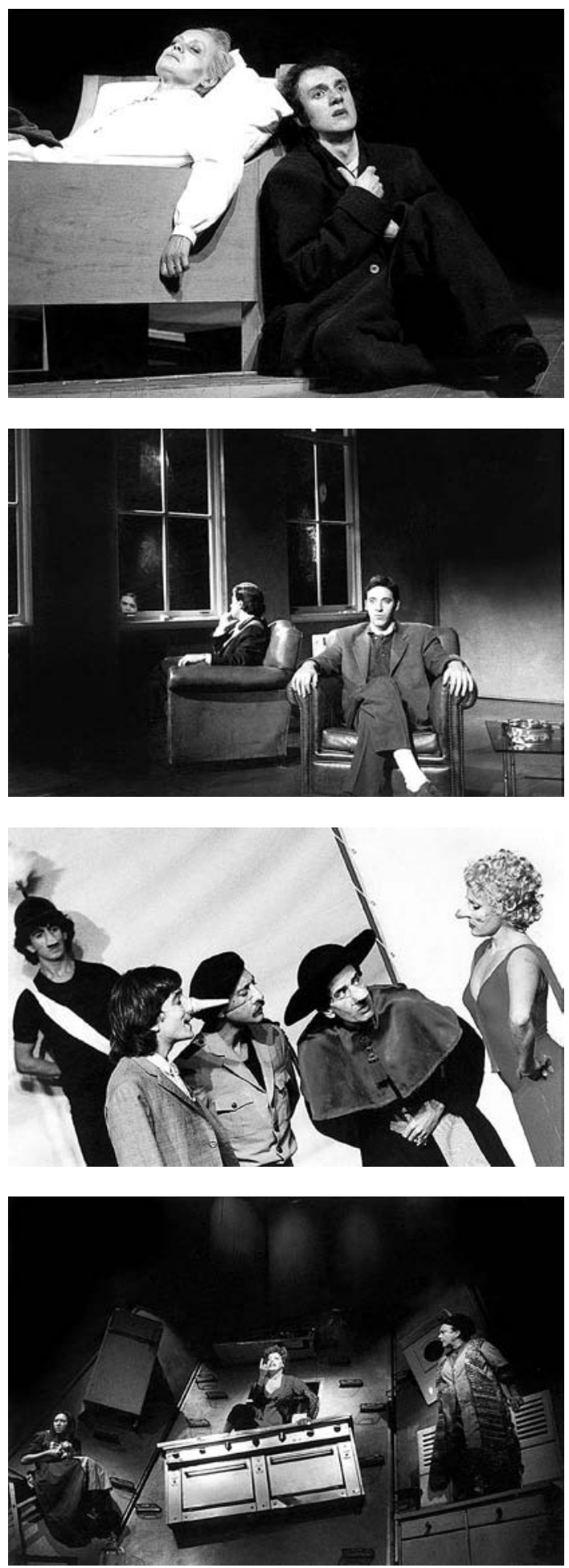

Haveria ainda que destacar a atenção muito particular dedicada por Vera San Payo de Lemos à especificidade exigida pelo teatro musical, de Brecht (Ascensão e queda da cidade de Mahagonny, Happy End, A ópera de três vinténs e 0 mar é azul, azul) a Stephen Sondheim (Sweeney Todd). É sempre com particular empenho e sedução que a tradutora nos descreve, nos seus relatos destes trabalhos, a fase de labor colectivo (muitas vezes, com a colaboração de músicos como, por exemplo, João Paulo Santos) em torno das versões portuguesas de muitas das canções que integram aqueles espectáculos, numa aposta decidida no alargamento generoso e eficaz da comunicação com o público.
Outro aspecto não menos importante da actividade da tradutora e dramaturgista é o facto de, para lá da sua relação privilegiada com o Novo Grupo/Teatro Aberto, Vera San Payo de Lemos ter colaborado com outras companhias, tais como o Grupo de Teatro de Letras (na adaptação de Os novos sofrimentos do jovem Werther, 1986), o Teatro da Rainha (na revisão de A hora do lobo ou A verdadeira história de Ah 0. 1985), o Teatro do Tejo (na tradução e dramaturgia de Coração na boca, de Shepard, 1991), o Bando (na tradução de Merlim, de Tankred Dorst, 2000) e o Teatro Nacional S. João (na tradução de 0 coração de um pugilista, de Lutz Hübner, 2002, e na tradução utilizada para legendagem electrónica de Cara de fogo, de Marius von Mayenburg). Fenómeno diverso, mas igualmente revelador da importância reconhecida ao seu trabalho, é, ainda, o facto de algumas estruturas continuarem a recuperar algumas das suas traduções para novos espectáculos, como aconteceu, em 2003, com Loucos por amor, de Sam Shepard, e acontece agora, em 2004, justamente, com Cara de fogo, de Marius von Mayenburg, em cena no Teatro da Comuna, numa encenação de João Mota.

Resulta quase como absurdo que, de entre a multiplicidade de textos estudados, traduzidos e reescritos por Vera San Payo de Lemos, só um número muito reduzido tenha sido publicado, como é o caso, para além das duas peças atrás referidas, de Oleanna, de David Mamet, 0 tempo e o quarto, de Botho Strauss, 0 coração de um pugilista, de Lutz Hübner, e os libretos de Ascensão e queda da cidade de Mahagonny e Sweeney Todd. Assinale-se, justamente por isso, com particular regozijo e louvor, a sua colaboração no projecto de publicação da obra dramática completa de Bertolt Brecht, iniciada já em 2003, com um primeiro volume, onde encontramos mais um informado texto seu dedicado à "Definição de um território: Os primeiros trabalhos do jovem Brecht" (Lemos 2003a). A publicação das traduções acaba por ser, afinal, a face mais visivel e duradoura de um trabalho que, no seu caso, surge também enriquecido pela experiência de docência e de investigação, nas áreas da Tradução e Dramaturgia e História do Teatro, no âmbito dos cursos de pós-graduação em Estudos de Teatro, oferecidos pela Faculdade de Letras de Lisboa, e do Centro de Estudos de Teatro, unidade instalada naquela mesma instituição universitária.

\section{5.}

Num sistema teatral como o nosso, que continua a depender, de um modo tão flagrante, da importação regular de experiências dramáticas estrangeiras, é importante, por um lado, que as operações de transferência se realizem de um modo consciente e consequente, e, por outro, é sempre de esperar que a divulgação sistemática e informada desses universos seja capaz, para além de exercitar a imaginação cénica dos nossos criadores teatrais, também de contribuir para o estímulo da produção dramática nacional.

Num ano em que se celebram trinta anos de democracia portuguesa, celebra-se também, aqui, através deste prémio e destas breves palavras que o tentam justificar, um percurso
Peer Gynt,

de Henrik Ibsen,

enc. João Lourenço,

Teatro Aberto, 2002

(Irene Cruz e

João Pedro Vaz),

fot. Ramon de Melo.

0 tempo e o quarto

de Botho Strauss,

enc. João Lourenço,

Teatro Aberto, 1993

(Virgílio Castelo e

Diogo Infante),

fot. João Lourenço.

Ubu português - 2002

Odisseia no Terreiro do

Paço

de João Lourenço,

José Fanha e

Vera San Payo de Lemos,

enc. João Lourenço,

Teatro Aberto, 1984

(Carlos Pisco, Miquel

Guilherme, Francisco

Pestana, António Feio e

Irene Cruzl.

fot. João Lourenço.

\section{As presidentes,}

de Werner Schwab, enc. João Lourenço, Teatro Aberto, 1996 (Maria João Abreu, Irene Cruz e Anna Paula), fot. João Lourenço. 
Obobo e a sua mulher esto

noite na Pancomédia,

de Botho Strauss,

enc. João Lourenço,

Teatro Aberto/TNSJ, 2003

(Sara Cipriano), fot. João Tuna.

de pesquisa e de criação singularmente atento e coerente, representativo de uma das muitas e diversas vias percorridas pelo teatro português nas últimas três décadas. Numa fase em que esse mesmo teatro português se mostra renovado por experiências empenhadas na interrogação de práticas e modelos estabelecidos - muitas vezes numa espécie de vertigem meta-teatral, tão fascinante como inquietante -, o destaque concedido a um percurso com a coerência de que se reveste este, aqui exposto, de Vera San Payo de Lemos não deve ser entendido como a valorização de um modelo sobre quaisquer outros, nem como um qualquer irreflectido prémio por "antiguidade", mas tão simplesmente - tão deliberadamente, acrescentaria - como o reconhecimento simbólico de um saber e de um fazer, onde se combinam, com a paixão e a profundidade que se tentaram demonstrar, o conhecimento da história, da teoria e da prática do teatro. Práticas e saberes com os quais criadores, espectadores e críticos continuarão, por certo, a dialogar, da forma mais lúcida, lúdica e reconhecida que a experiência teatral for capaz de, renovadamente, nos proporcionar.

\section{R eferências bibliográficas*}

AALTONEN, Sirkuu (2000), Time-Sharing on Stage:Drama Translation in Theatre and Society, Clevedon, Multilingual Matters.

CARDULLO, Bert (1995), What is Dramaturgy?, New York, Peter Lang Publishing. CARRINGTON, Maria Cristina (1991), "Herr Puntila und Sein Knecht MattilO Senhor Puntila e o seu criado Matti e Der Gute Mensch von Sezuan/A alma boa de Se-Tsuan - A boa pessoa de Setzuan", in Maria Manuel Gouveia Delille (coord.), Do pobre B.B. em Portugal:Aspectos da recepção de Bertolt Brecht antes e depois do 25 de Abril de 1974, Coimbra, Editora Estante, pp. 241-288.

CARVALHO, Paulo Eduardo (1999), "'Pérolas, esferas e circulos': A tradução de teatro", Teatro Escritos: Revista de Ensaio e Ficção, Lisboa, IPAE e Livros Cotovia, pp. 50-69.

- - (2002), "Modalidades de negociação da alteridade: 0 caso do teatro irlandês contemporâneo nos palcos portugueses", in Maria do Carmo Oliveira e Alexandra Lopes (org.), Deste lado do espelho. Estudos de tradução em Portugal: Novos contributos para a história da literatura portuguesa, Lisboa, Universidade Católica Editora, pp. 203-228.

DORT, Bernard (1986), "L'état d'esprit dramaturgique", Théâtre/Public, n 67 Dramaturgie, Janeiro-Fevereiro, pp. 8-12.

LEMOS, Vera San Payo de (1984), "Sobre A boa pessoa de Setzuan, de Bertolt Brecht", in Programa de A boa pessoa de Setzuan, Lisboa, Novo Grupo, $s / p$

- - (1986), "Sobre este espectáculo", in Programa de Mãe Coragem e os seus filhos, Lisboa, TNDMII, pp. 37-47.

- - (1988a), "Fragmentos de um discurso dramatúrgico sobre Romeu e Julieta", in Programa de Romeu e Julieta, Lisboa, Novo Grupo, s/p.

- - (1988b), "O senhor B. atravessa a rua", in Programa de A rua, Lisboa, Novo Grupo, s/p.

- - (1994), "Em pano de fundo: Pontos e linhas de uma prática dramatúrgica", in Eugénia Vasques et al. (ed.), Fragmentos da memória: Teatro independente em Portugal (1974-1994), Catálogo da exposição realizada no âmbito dos Encontros ACARTE 1994, Lisboa, Acarte/F.C.G., pp. 64-70.

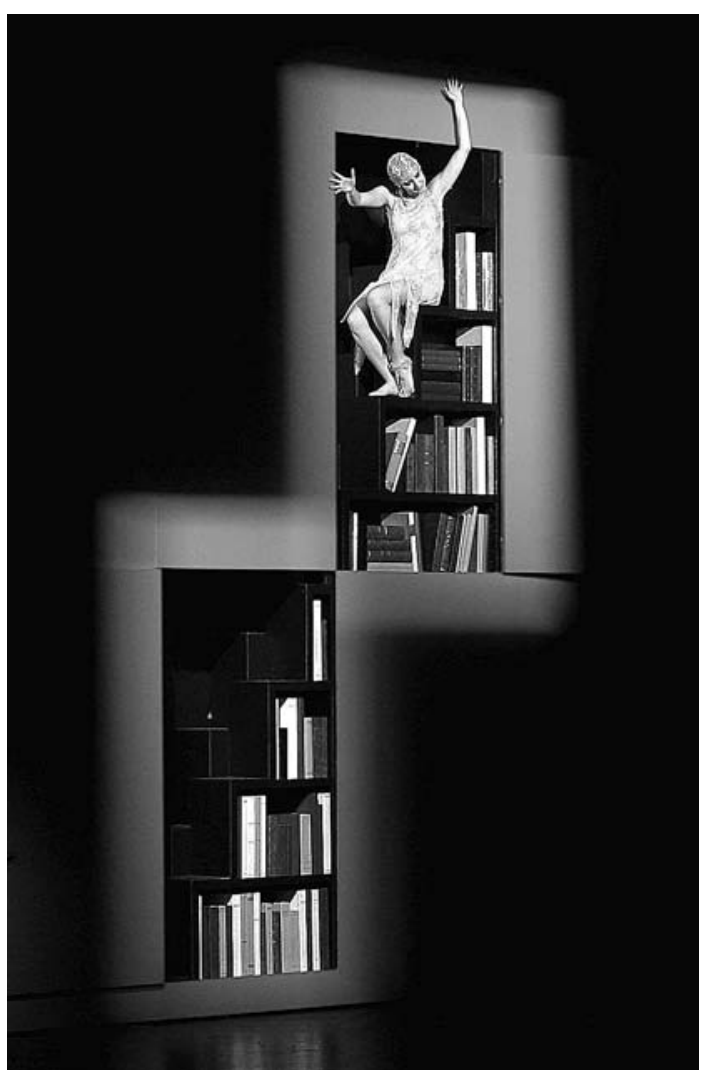

- - (1998), "A liberdade pois sim mas porém: Aspectos de uma tradução de A ópera de três vinténs, de Brecht/Weill", Adágio. Revista do Centro Dramático de Évora, n²1/22, Junho de 1998/Janeiro de 1999, Colóquio Internacional Bertolt Brecht, pp. 214-221.

- - (2003a), "Definição de um território. Os primeiros trabalhos do jovem Brecht", in Bertolt Brecht, Teatro 1, Lisboa, Cotovia, pp. 17-35.

- - (2003b), "Caras e corações: Retrato de Botho Strauss", in Programa de O bobo e a sua mulher esta noite na Pancomédia, Lisboa, Teatro Aberto/Novo Grupo, pp. 15-19; Duas Colunas, n 6, Setembro, p. 14.

NUNES, Maria Leonor (2003), "Vera San Payo de Lemos: Das palavras a actos", Jornal de Letras, 24 de Dezembro, p. 9

PAIS, Ana (2004), 0 discurso da cumplicidade. Dramaturgias contemporâneas, Lisboa, Edições Colibri.

SARRAZAC, Jean-Pierre (2002), La parabole ou l'enfance du théâtre, Paris, Circé.

TEIXEIRA, Maria Antónia (1998), "A recepção portuguesa de Mutter Courage und ihre Kinder/Mãe Coragem e os seus filhos", in Maria Manuela Gouveia Delille (coord.), Do pobre B.B. em Portugal:A recepção dos dramas 'Mutter Courage und ihre kinder' e 'Leben des Galilei', Coimbra, Livraria Minerva, pp. $19-100$.

VERSÉNY, Adam (2003), "Dramaturgy/Dramaturg", in Dennis Kennedy (ed.), The Oxford Encyclopedia of Theatre and Performance, Oxford, O.U.P., pp. 386-88.

* A identificação mais exaustiva dos textos de Vera San Payo de Lemos, alguns deles referidos, mas não citados, nesta apresentação, deve ser procurada no Anexo seguinte.

Para mais informações sobre a actividade de Vera San Payo de Lemos, consultese a página do Novo Grupo/Teatro Aberto e a CETBase, do Centro de Estudos de Teatro: <www.teatroaberto.com $>$ e $<$ www.fl.ul.pt/centro-estudosteatro.htm>. 

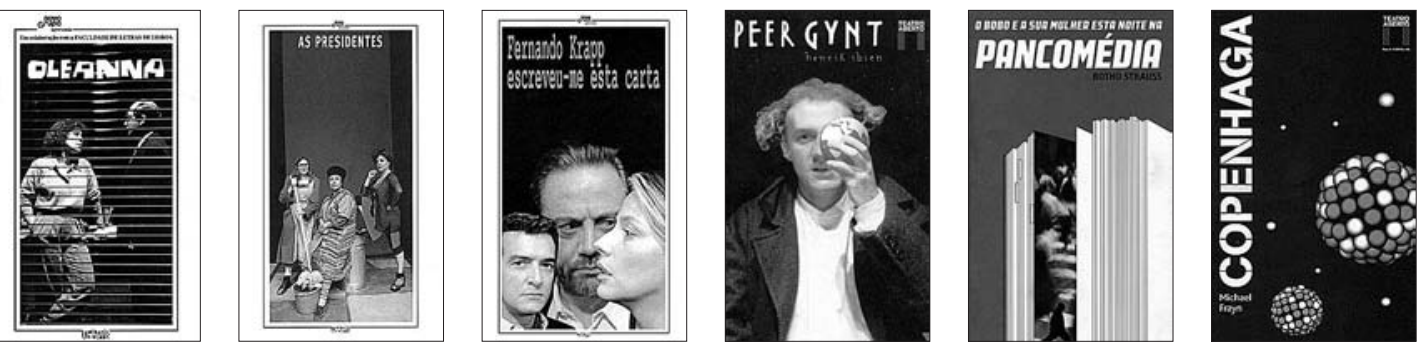

\section{ANEXO \\ Textos publicados por Vera San Payo de Lemos}

(1980) "Vamos contar a história de Baal", in Programa de Baal, Lisboa, Teatro da Trindade, 1980, s/p; reproduzido in Bertolt Brecht, Baal, versão de João Lourenço e José Fanha, Lisboa, Barca Nova, 1982, pp. 7-31.

(1982) "Sobre Oiçam como eu respiro, de Dario Fo/Franca Rame", in programa de Oiçam como eu respiro, Lisboa, Teatro Aberto/Novo Grupo, s/p.

(1983, "Nikolai Erdman e o O suicidário", in Programa de O suicidário, Lisboa, Teatro Aberto/Novo Grupo, s/p.

(1984) "Sobre A boa pessoa de Setzuan, de Bertolt Brecht", in Programa de A boa pessoa de Setzuan, Lisboa, Teatro Aberto/Novo Grupo, s/p.

- - "Conversa para ouvidos de gravador", in Programa de Ubu português: 2002 Odisseia no Terreiro do Paço, Lisboa, Teatro Aberto/Novo Grupo, s/p.

(1985) "Diário de trabalho", in Programa de Ascensão e queda da cidade de Mahagonny, Lisboa, TNSC, s/p.

- - "Do fundo da caixa... para o mundo maravilhoso", in Programa de Tu e eu, Lisboa, Teatro Aberto/Novo Grupo, s/p.

(1986) "Sobre este espectáculo", in Programa de Mãe Coragem e os seus filhos, Lisboa, TNDMII, pp. 37-47.

(1987) "O jardim é como as cerejas", in Programa de Ojardim das cerejas, Lisboa, Teatro Aberto/Novo Grupo, s/p.

(1988) "O senhor B. atravessa a rua", in Programa de A rua, Lisboa, Teatro Aberto/Novo Grupo, s/p.

- - "Fragmentos de um discurso dramatúrgico sobre Romeu e Julieta", in Programa de Romeu e Julieta, Lisboa, Teatro Aberto/Novo Grupo, s/p.

(1989) "Sobre Happy End: Happy End procura-se", in Programa de Happy End, Lisboa, Teatro Aberto/Novo Grupo, s/p.

(1990) "Estações de um percurso: Através da solidão dos campos de algodão", in Programa de Na solidão dos campos de algodão, Lisboa, Teatro Aberto/Novo Grupo, s/p.

- - "Desejo loucos sob os ulmeiros por amor: Conversa entre Eugene O'Neill e Sam Shepard", in Programa de Desejo sob os ulmeiros e Loucos por amor, Lisboa, Teatro Aberto/Novo Grupo, s/p.

(1991) "Salve Semion!", in Programa de Osuicidário, Lisboa, Teatro Aberto/Novo Grupo, s/p.

(1992) "Sabor a mel, sabor a fel", in Programa de Sabor a mel, Lisboa, Teatro Aberto/Novo Grupo, s/p.

- - "Aópera de três vinténs. Uma peça em pedaços para um mundo em pedaços", in Programa de A ópera de três vinténs, Lisboa, Teatro Aberto/Novo Grupo, s/p.

(1993) "Visões de Marie", in Programa de 0 tempo e o quarto, Lisboa, , Teatro Aberto/Novo Grupo, s/p.

(1994) "Diálogo - Drama - Duelo: Sobre Oleanna, de David Mamet", in Programa de Oleanna, Lisboa, Teatro Aberto/Novo Grupo, s/p.

- - "Onde o inferno não são os outros", in Programa de Alguém olhará por mim, Lisboa, Teatro Aberto/Novo Grupo, s/p.

-- "Em pano de fundo: Pontos e linhas de uma prática dramatúrgica", in Eugénia Vasques et al. (ed.), Fragmentos da memória: Teatro independente em Portugal (1974-1994), Catálogo da exposição realizada no âmbito dos Encontros ACARTE 1994, Lisboa, Acarte/F.C.G., pp. 64-70.

(1995) "Geografia exterior e interior no caminho para Meca", in Programa de O caminho para Meca, Lisboa, TNDMII, pp. 15-17
- - "Ensaio em três compassos", in Programa de 0 ensaio, Lisboa, Teatro Aberto/Novo Grupo, s/p.

(1996) "Chicago ou Tahiti? Um processo de ensino/aprendizagem em Im Dickicht de Brecht", in Rita Iriarte (coord.), Ensaios de literatura e cultura alemã Coimbra, Minerva, pp. 143-159.

- - "Sobre As presidentes, de Werner Schwab", in Programa de As presidentes, Lisboa, Teatro Aberto/Novo Grupo, s/p.

(1997) "Sobre Fernando Krapp escreveu-me esta carta", in Programa de Fernando Krapp escreveu-me esta carta, Lisboa, Teatro Aberto/Novo Grupo, s/p.

- - "Sweeney Todd em Lisboa. Notas em cinco andamentos", in Programa de Sweeney Todd, Lisboa, TNDMII, PP. 50-51, em colaboração com João Lourenço.

- - "Fios de histórias", in Programa de Água salgada, Lisboa, Teatro Aberto/Novo Grupo, s/p.

(1998) "A liberdade pois sim mas porém: Aspectos de uma tradução de $A$ ópera de três vinténs, de Brecht/Weill", Adágio. Revista do Centro Dramático de Évora, n 21/22, Junho 1998/Janeiro 1999, Colóquio Internacional Bertolt Brecht, pp. 214-221.

- - "Cai neve em Abril. Visões do apocalipse na era pós-cristã", in Programa de Ás vezes neva em Abril, Lisboa, Teatro Aberto/Novo grupo, s/p.

- -(1988) "Luz de Inverno:Um debate em luso - fusco", in Programa de Luz de Inverno, Teatro Aberto/Novo Grupo, s/p.

(1999) "Sobre Quase. Em ponto de interrogação", in Programa de Quase, Lisboa, Teatro Aberto/Novo Grupo, s/p.

- - "Outras faces da moeda", in Programa de Top Dogs, Lisboa, Teatro Aberto/Novo Grupo, s/p.

(2000) "Vozes vindas das trevas", in A palavra eo canto:Miscelânea de homenagem a Rita Iriarte, Lisboa, Edições Colibri, pp. 341-352.

- - "Trabalho de Campo", in Programa de Lucefécit, Lisboa, Novo Grupo, s/p.

- - "Coisas com vida, coisas sem vida" e "Nos entretextos", in Programa de Até mais ver, Lisboa, Teatro Aberto/Novo Grupo, s/p.

(2001) "O sonho da aflição", in Programa de A visita, Lisboa, Teatro Aberto/Novo Grupo, s/p.

(2002) "Antes de Pentecostes", in Programa de Peer Gynt, Lisboa, Novo Grupo, pp. 67-73.

- - "As máscaras diante da cara", in Programa de José e Maria, Lisboa, Teatro Aberto/Novo Grupo, pp. 66-69.

(2003) "Na encruzilhada", in Programa de Demónios Menores, Lisboa, Novo Grupo, pp. 45-49.

- - "Caras e corações: Retrato de Botho Strauss", in Programa de O bobo e a sua mulher esta noite na Pancomédia, Lisboa, Teatro Aberto/Novo Grupo, pp. 15-19; Duas Colunas, no 6, Setembro, p. 14.

- - "Momentos, apontamentos", in Programa de 0 bobo e a sua mulher esta noite na Pancomédia, Lisboa, Teatro Aberto/Novo Grupo, pp. 48-51.

- - "Definição de um território. Os primeiros trabalhos do jovem Brecht", in Bertolt Brecht, Teatro 1, Lisboa, Cotovia, pp. 17-35.

(2004) "Entre os lagos, debaixo da estrela polar", Duas Colunas, n 8, Janeiro, p. 17.

- - "A arte de ocultar a arte", in Programa de A forma das coisas, Lisboa, Teatro Aberto/Novo Grupo, pp. 40-43. 

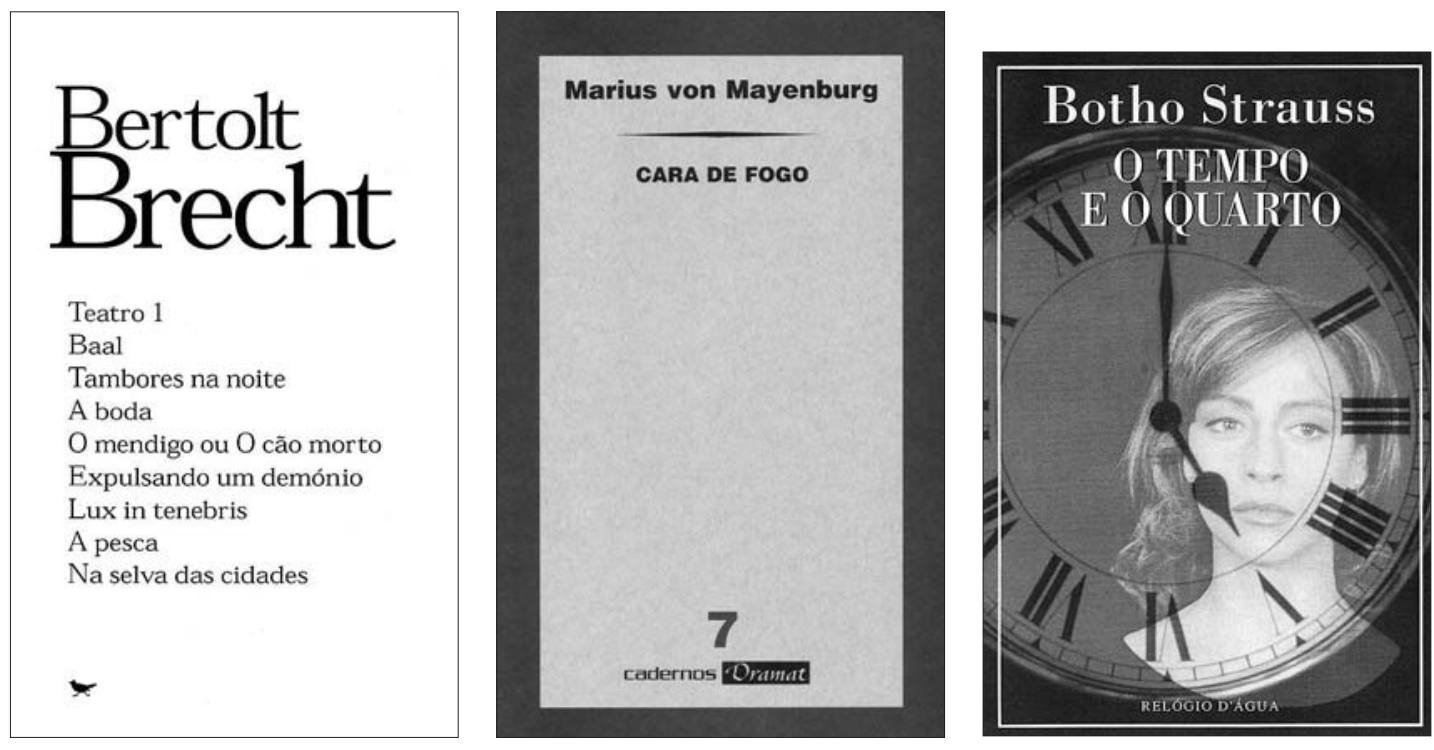

\section{Traduções publicadas}

BRECHT, Bertolt e Kurt Weill (1985), Ascensão e queda da cidade de Mahagonny, libretto, trad. João Lourenço, José Fanha e Vera San Payo de Lemos, in Anexo ao Programa de Ascensão e queda da cidade de Mahagonny, Lisboa, TNSC.

BRECHT, Bertolt (2003), Teatro 1, trad. Vera San Payo de Lemos (Baal, A boda, Expulsando um demónio, Lux in Tenebris, Na selva das cidades), Jorge Silva Melo (Baal, Tambores na noite, A boda, Na selva das cidades) e José Maria Vieira Mendes (Baal, 0 mendigo ou o cão morto, A pesca, Na selva das cidades), Lisboa, Livros Cotovia.

HÜBNER, Lutz (2002), O coração de um pugilista e Creeps: drama, trad. Vera San Payo de Lemos e Ana Maria Dias Pires, Montemor-o-Novo, A Cobra Laranja. MAMET, David (1994), Oleanna, trad. Vera San Payo de Lemos, Lisboa, Colibri.

MAYENBURG, Marius von (2001), Cara de fogo, trad. Vera San Payo de Lemos, Cadernos Dramat 7, Porto e Lisboa, Centro de Dramaturgias Contemporâneas e Livros Cotovia.

SHEPARD, Sam (1990), Loucos por amor, trad. Vera San Payo de Lemos, Lisboa, Relógio d'Água.

SONDHEIM, Stephen (1997), Sweeney Todd, libreto, trad. João Lourenço, José Fanha e Vera San Payo de Lemos, Lisboa, TNDMII.

STRAUSS, Botho (1993), O tempo e o quarto, trad. Vera San Payo de Lemos, Lisboa, Relógio d'Água.

WEKWERTH, Manfred (1981), Notas de trabalho no Berliner Ensemble, trad. Ana Gaspar, Anabela Mendes, Beatriz Coelho, Leonor Dias, Vera San Payo de Lemos, Lisboa, APTA (Associação Portuguesa de Teatro Amador). 